\title{
RELIGIOUS TOLERANCE OF MINANGKABAU AND BATAK ETHNIC STUDENTS IN XAVERIUS BUKITTINGGI HIGH SCHOOL
}

\author{
Arjoni $^{1}$, Charles $^{2}$, Intan Sari $^{3}$
}

First Received: $2^{\text {nd }}$ January 2020

Final Proof Received: $15^{\text {th }}$ May 2020

Abstract: This article is based on the results of a mini-research that aims to describe the religious tolerance of Minangkabau and Batak ethnic students at Xaverius Bukittinggi High School in the academic year 2019/2020. This research uses a quantitative approach. The steps in this research are conducting preliminary studies, literature studies, data collection, data analysts and conclusions. The population of this study, XII Bukittinggi ethnic group Minangkabau and Batak ethics XII grade students. Sampling with purposive sampling technique. Data collection using a questionnaire, data analysis techniques with normality, homogeneity, and T-test. The results of this study illustrate the religious tolerance of ethnic Minangkabau and Batak students dominated by the tolerant category. There was no significant difference in religious tolerance between ethnic Minangkabau and Batak students. However, differences in religious tolerance scores were found between ethnic Minangkabau students and Batak students on the aspect of maintaining independence in practising religion and respecting the practice of diversity. The Batak students are a minority population in Xaverius Bukittinggi high school while the majority are Minangkabau students population. Development of religious tolerance Students of the Minangkabau ethnic group and the Batak ethnic group at Xaverius High School tend to be equally tolerant and potentially more tolerant when the curriculum and education at the school are carried out properly. The results of this study can be used as consideration for developing religious-spiritual strength counselling and arranging cross-cultural counselling and guidance programs in high schools.

Keywords: religious tolerance, minangkabau etnic and batak etnic

JOMSIGN: Journal of Multicultural Studies in Guidance and Counseling Website: http://ejournal.upi.edu/index.php/JOMSIGN

Permalink: http://ejournal.upi.edu/index.php/JOMSIGN/article/view/6314

How to cite (APA): Arjoni, Charles, Sari, I. (2020). Religious Tolerance of Minangkabau and Batak Ethnic Students in Xaverius Bukittinggi High School. JOMSIGN: Journal of Multicultural Studies in Guidance and Counseling, 4(1), Page. $79-100$

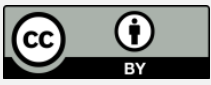

This is an open-access article distributed under the terms of the Creative Commons Attribution 4.0 International License, which permits unrestricted use, distribution, and reproduction in any medium, provided the original work is properly cited.

\footnotetext{
${ }_{1}^{1}$ Arjoni, IAIN Bukittinggi, Indonesia, Email: arjonimelamindo@gamail.com

2 Charles, Islamic Education Departemen, IAIN Bukittinggi, Indonesia Email: charlesmalinkayo.cc@gamail.com

${ }^{3}$ Intan Sari, Guidance and Counseling Departemen, IAIN Bukittinggi, Indonesia Email: intansari@gamail.com
} 


\section{INTRODUCTION}

Religious tolerance is a basic element needed to foster harmony housing in the lives of multicultural societies. Developing an attitude of mutual trust and understanding of differences is an entry point for the realization of dialogue and harmony among religious believers in society. Religious tolerance should become a collective awareness of all community groups; from children, adolescents, adults, to parents, both students, students, employees, bureaucrats, and other professionals, to avoid conflicts between religious believers, achieve the same goals based on togetherness, inclusive attitude, respect, and mutual understanding related to the implementation of rituals and certain doctrines of each religion (Casram, 2016; Ahsanul Khalikin, 2016). Tolerance is a fundamental virtue in democratic life, but it has ambivalent power which is manifested in two forms, namely a solid form and a democratic form (Mokodenseho, 2017)

Religious tolerance, namely attitudes and behaviours that are open, independent, respectful and build positive social interactions with individuals and interfaith groups who believe and worship according to their religion and or beliefs, so that a harmonious, peaceful and harmonious life in society, nation and religion (Diane, 2004; Davis, 2010; Pamungkas, 2014). Aspects of religious tolerance, namely attitudes and behaviour; a). open (understanding, accepting and maintaining the reality of the different concepts of faith and worship of each religion and stream of beliefs), b). independence in practising the faith and worship of each religious adherent and/or hereditary beliefs, c). respect the concept of the development of faith and worship of adherents of religion and or beliefs and $\mathrm{d}$ ). Building positive interactions and communication across religious adherents and/or beliefs (Diane, 2004 Davis, 2010; Pamungkas, 2014). Factors that influence the development of religious tolerance can be seen from internal factors (knowledge, interests, attitudes, skills and experience) and externally influenced by the community and mass media environment (H. Bahari, 2010).

Research report (Dwi Winanto Hadi, 2017) revealed; "The results of the study of tolerance in Indonesia and its factors based on the 2014 SUSENAS data show that tolerance towards the activities carried out by religious adherents in Indonesia tends to be low, while the factors affecting tolerance are education level, economic status, classification of residence, employment status, gender and age "(Dwi Winanto Hadi, 2017). Furthermore (Hermawati 
et al., 2017) revealed; "Religious issues are still a strong factor to facilitate ingroup and out-group identity-based sentiments, making them vulnerable to conflict".Toto Sunarya (2011), revealed; "Religious tolerance is an actual problem of all time. The actualization of religious tolerance in Indonesia is considered far from ideal, therefore socialization and coaching need to be improved "(Suryana, 2011)

From some of the results of the above studies recommending religious tolerance in the community, especially in the educational environment is needed. (H. Bahari, 2010) also mentions Students as the hope of the nation's future in carrying out the mandate of leadership and social change agents, presumably must be equipped with sufficient knowledge, experience, and wisdom in addressing the nation's plurality which is indeed very high. For this reason, religious tolerance research needs to be done among students $(\mathrm{H}$. Bahari, 2010). Besides university students, students also need attention. This is reinforced from the recommendations of research results Umi Muzayanah said; "The attitude of intolerance has spread to students, therefore further research is needed among students"(Muzayanah, 2017)

In-Law No. 20 of 2003 concerning the National Education System implicitly regulates religious tolerance education, that is, education is carried out democratically and fairly and is not discriminatory by upholding human rights, religious values, cultural values, and national pluralism. Violation of education that is democratic and tolerant, three basic requirements must be met. In-Law No. 20 of 2003 concerning the National Education System implicitly regulates religious tolerance education, that is, education is carried out democratically and fairly and is not discriminatory by upholding human rights, religious values, cultural values, and national pluralism. First, the practice of education always emphasizes the principle of justice so that all students receive a fair and equal education. Second, the learning process is kept away from the nature of bias and stereotypes. Third, the learning process leads to the development of students' awareness of themselves, respecting other cultures outside of themselves, and being able to work together amidst existing cultural differences (Rustam Ibrahim, 2013).

The phenomenon in the field was found not yet to be a complete picture of religious tolerance education implemented in all provinces in Indonesia. Among the provinces that did not escape the attention, namely the province of West Sumatra. The 2016 Ministry of Religion research centre found religious 
tolerance in Padang City to be relatively low. The intolerance aspect that is quite prominent from the aspects of establishing houses of worship, marriages of different religions, and fulfilling the right to education (Ahsanul Khalikin, 2016). Duski Samad, chairman of the West Sumatra Religious Harmony Forum (FKUB) revealed; "The results of the study are unfortunate and further research is needed in-depth" (Samad, 2019) During this time West Sumatra is known as an area with a strong population to practice Islam and known philosophy, the customary based syarak, syariah basandi Kitabullah (ABSSBK). This phenomenon is reflected in the city of Padang but has not yet become a concern in multicultural areas such as in the city of Bukittinggi.

Bukittinggi is a city of tourism, trade, and education (Yasmarni, 2018). Bukittinggi is known as the city of Education because there are many boarding schools and other schools that are the destination of students from various regions and ethnic migrants to gain knowledge. Bukittinggi City population consists of Minangkabau ethnics, Malay, Batak, Aceh, Mentawai, Nias, Javanese, Sundanese, Chinese and other ethnicities from each of the regions scattered in the archipelago (Yasmarni, 2018). In the city of Bukittinggi, some schools have ethnic diversity students namely Xaverius Bukittinggi High School. Xaverius Bukittinggi High School seeks to care for ethnic diversity, therefore the educational process in the school is of concern to researchers in the development of religious tolerance. The student population that dominates at the school is the Minangkabau and Batak ethnic groups. Students of the Minangkabau and Batak ethnic groups have their characteristics, both cultural diversity and religious diversity, but besides that, it also has similarities and interrelated brotherhood.

Minangkabau ethnic students are known for their culture that integrates Islamic values in their lives, while Batak ethnic groups are generally devout Christians, Catholics, and some Muslims. From the side of similarity between ethnic students Minangkabau and Batak ethnic feel the same population originating and inhabiting the Sumatra region known as fertile areas and beautiful nature. The beauty of nature can be reflected in the character and social interaction of the two groups. In the process of interaction and communication between religions and cultures, Batak and Minangkabau ethnic students in Xaverius Bukittingi High School have not yet revealed a picture of religious tolerance behaviour, so a deeper study is needed. 
The results of this study can be used to develop students' spiritual strength counselling in Bukittinggi City High Schools and manage crosscultural Guidance and Counseling programs in high schools.

\section{METHOD}

This research approach is quantitative with a comparative design. This study explains the religious tolerance of ethnic Minangkabau students, religious tolerance of ethnic Bataks students and differences in religious tolerance of ethnic Minangkabau and Batak ethnic students. The steps of this research are preliminary studies, literature studies, data collection, data analysis, and research conclusions. The population of this research is the class XII students majoring in science and social studies at Xaverius Bukittinggi high school, totalling 119 people. The population is students who have considerable experience in interacting with fellow school residents. The sampling technique uses a purposive sampling technique by identifying and verifying students of the Minangkabau ethnic and Batak ethnic. To compare the two groups proportionally, researchers conducted a homogeneity test so that the quality balance of each group was known to be compared. The results of identification and verification were found as many as 40 students, consisting of 20 ethnic Minangkabau students and 20 ethnic Batak students. The ethnic Minangkabau students in question are the students who are identified and the individual's recognition comes from and adheres to the Minangkabau culture, while the Batak ethnic students are the students who are identified and the individual's recognition comes from and adheres to the Batak culture.

The reason researchers researched this population was found in the field phenomenon (Xaverius Bukittinggi High School) to have a diverse student population of ethnic, cultural and religious backgrounds. The dominant population among several ethnic group students at the school are Minangkabau ethnic and Batak ethnic students. Both of these ethnic groups when observed in social interactions at school have a mutual influence on other ethnic groups. communication and interaction of each ethnic group have been established, but not yet closely connected. This condition has the potential to lead to religious intolerance if the atmosphere and educational process at the school has not yet created an atmosphere and the process of religious tolerance learning effectively. Besides that, it was found that there were no religious and learning facilities available to guarantee the 
implementation of religious activities at school. Noting these conditions and phenomena requires further and in-depth research to get a picture of religious tolerance among Minangkabau and Batak ethnic students at Xavaerius Bukittinggi High School. Data collection techniques in this study used a questionnaire on the scale of religious tolerance referred to from several theories of religious tolerance namely (Diane, 2004; Davis, 2010; and Pamungkas, 2014), were subsequently synthesized by researchers without changing the meaning and substance of religious tolerance in question into the student tolerance questionnaire. This questionnaire consists of several aspects, indicators. The religious tolerance aspects in question are aspects of attitude and behaviour; a). open (understand, accept and maintain the reality of differences in the concepts of faith and worship of each religion and the flow of belief), b). Freedom in practising the faith and worship of each adherent and religious belief, c). respect the concepts of developing faith and religious worship and the flow of beliefs and d). positive interaction and communication from each religious adherent and the flow of belief (Diane, 2004; Davis, 2010; Pamungkas, 2014). After understanding the lattice of the questionnaire, I then compiled several positive and negative statement items.

After the questionnaire was compiled, then theoretical and empirical validations were performed. Theoretical validation is carried out by experts in the field of religious tolerance namely Wedra Aprison, Nunu Burhanuddin and Aprinaldi. From the theoretical validation results considered from every aspect, the indicators and content of the questionnaire statements need to be revised including the need to be clearly explained and some content of statement items and adjusted to the level of understanding and experience of students in school. Then the questionnaire was corrected as suggested by the Validator. After the questionnaire was theoretically validated, the next questionnaire was empirically validated by testing the questionnaire in the field. As for the sample students to conduct an empirical validation test for this questionnaire, superior students in class XII were 30 students from various religions and cultures. After testing the questionnaire, several questionnaire items were found that were valid and not yet valid. Of the 66 questionnaire items, 56 items were valid and 10 items were not yet valid, thus 56 questionnaire items were used for research data collection, while 10 items that were not yet valid were deleted. After an empirical validation test, the researchers then tested the reliability test. From the reliability test results of these items, it is known that Alpa Cronbach's religious tolerance instruments 
are 0.958 ( $\mathrm{r}$ arithmetic) $>0.80$ ( $\mathrm{r}$ table) interpreted the questionnaire items are consistent and can be used to collect research data. After the research data is collected, the researcher then tabulates the data and scores the data. Alternative answers to this questionnaire consisted of always, often, sometimes, rarely, and never, researchers did to know the frequency of religious tolerance or behaviour experienced by students during interactions with fellow residents of Xaverius Bukittinggi High School.

Furthermore, I calculated the number of scores of data collected and grouped based on the categorization of the interval that has been determined, then calculated the frequency, and the percentage of responses from respondents. The categorizing formula is; Interval $=$ the largest data-smallest data/ number of groups (Agus Irianto: 2004: 12). Intervals $=280-56=224 / 3=$ 74,6667 , then fulfilled to 75 . Next, after data processing is done, it is known the categorization criteria and described as follows:

Table 1. Description of religious tolerance of Xaverius Bukittinggi High School Students

\begin{tabular}{cccc} 
Category & Interval & F & \% \\
\hline Tolerance & $\geq 224$ & 0 & 0 \\
\hline Tolerant enough & $148-223$ & 0 & 0 \\
\hline Intolerance & $\leq 147$ & 0 & 0 \\
\hline The amount & & 40 & 100 \\
\hline
\end{tabular}

In describing religious tolerance, Xaverius Bukittinggi secondary school students were identified as consisting of religious tolerance among ethnic Minangkabau and Batak students, then conducting a normality test. The purpose of conducting a normality test is to determine whether the distribution of data obtained follows or approaches the normal distribution law (Nisfiannoor, 2009: 91). Calculation of the normality test in this study using the Kolmogorov Smirnov test and assisted by the application of the SPSS 25 program. Criteria for data are normally distributed if the significance value> 0.05 (Idris, 2000: 40). The results of the normality test are explained in the following table:

Table 2. Normality Test

\begin{tabular}{lccc} 
& \multicolumn{4}{c}{ Kolmogorov-Smirnov } \\
\cline { 2 - 4 } & Statistic & Df & Sig. \\
\hline Minang & .153 & 20 & $.200^{*}$ \\
\hline Batak & .188 & 20 & .062 \\
\hline
\end{tabular}

From table 2 above shows, the significance value of Minangkabau ethnic students $0.200>0.05$, and the significance value of Batak ethnic students 
0.062> 0.05 then the data is nominal distribution. After the data is declared to be normally distributed, the homogeneity test is then performed. The homogeneity test aims to determine whether the data variance between groups tested is different or not, the variance is homogeneous or heterogeneous (Nisfiannoor, 2009). The homogeneity test in this study uses Levene's test with criteria if the significance value> 0.05, then there is no difference between the two data groups or homogeneous data, whereas if the significance value $<0.05$ then the data is not homogeneous (Nisfiannoor), 2009). After processing the data, the homogeneity test results can be seen in the following table:

Table 3. Homogeneity Test

\begin{tabular}{llrrrr}
\hline \multirow{2}{*}{$\begin{array}{l}\text { Religious } \\
\text { Tolerance }\end{array}$} & $\begin{array}{c}\text { Levene } \\
\text { Statistic }\end{array}$ & df1 & \multicolumn{1}{c}{ df2 } & \multicolumn{1}{c}{ Sig. } \\
\cline { 2 - 6 } & Based on Mean & .478 & 1 & 38 & .494 \\
\cline { 2 - 6 } & Based on Median & .400 & 1 & 38 & .531 \\
\cline { 2 - 6 } & $\begin{array}{l}\text { Based on Median and with } \\
\text { adjusted df }\end{array}$ & .400 & 1 & 36.395 & .531 \\
\cline { 2 - 6 } & Based on trimmed mean & .381 & 1 & 38 & .541 \\
\hline
\end{tabular}

From these data obtained a significance score of 0.494. This shows that $p=0.494>0.05$, then the data are homogeneous. Based on the results of prerequisite test calculations the data assumption is homogeneous and normally distributed, so the next hypothesis test is performed using the T-test (Independent Sample T-Test). The hypothesis of this study are Ho; there is no significant difference in religious tolerance among Minangkabau ethnic students and Batak ethnicity at Xaverius Bukittinggi High School.

\section{FINDINGS AND DISCUSSIONS}

This study aims to describe the religious tolerance of ethnic Minangkabau students and Batak ethnic students in Xavarius Bukittinggi High School. The steps of the results of this study are explained; a). The religious tolerance of ethnic Minangkabau students at Xavarius Bukittinggi High School, b). The religious tolerance of ethnic Batak students at Xaverius Bukittinggi High School, c). Comparison of religious tolerance of ethnic Minangkabau students and Batak ethnic students in Xaverius Bukittinggi high school, to find out more can be seen in the following research: 


\section{A. Description of religious tolerance Minangkabau ethnic students in Xaverius Bukittinggi high school}

The Minangkabau ethnic students at Xaverius High School are the majority and religious population of Islam. Interaction and socialization have been practised in daily life, both at school and in other general public. The description of religious tolerance of ethnic Minangkabau students at Xaverius Bukitinggi High School in class XII can be seen in the following table:

Table 4. Description of religious tolerance of ethnic Minangkabau students at Xaverius Bukittinggi High School

\begin{tabular}{llll}
\hline Category & Interval & F & \% \\
\hline Tolerance & $\geq 224$ & 14 & 70 \\
\hline Tolerant enough & $148-223$ & 6 & 30 \\
\hline Intolerance & $\leq 147$ & 0 & 0 \\
\hline \multicolumn{2}{c}{ Amount } & 20 & 100 \\
\hline
\end{tabular}

From the description of the results of the study in the above table, it can be interpreted that religious tolerance of ethnic Minangkabau students is category tolerant as many as 14 people (70\%), the category is quite tolerant as many as 6 people (30\%), while the intolerant category is zero $(0 \%)$. These results can be understood religious tolerance Minangkabau ethnic students in Xaverius Bukittinggi high school dominated by tolerance, it means the attitude and behaviour of Minangkabau ethnic students are open, independent, respectful and build positive social interactions among students across religions in achieving a harmonious, peaceful and harmonious life both within the school environment and in the community generally tolerant.

The results of this study reinforce the results of research (A.Hakim, 2012) states; "There are several potentials that can create harmonious and integrative relationships among religious and other ethnic groups in West Sumatra, as there are values of local Minangkabau ethnic wisdom such as; a). Minangkabau ethnics uphold equality and balance with the term, dimaa bumi dipijak disinan langik di junjung (where the earth is trampled where the sky is upheld), namely the principle of adapting to society wherever located, regardless of ethnicity and religion, b). the existence of lamak dek awak katuju dek urang (good for us, people are also happy), as for the meaning of culture that reflects the attitude of togetherness in community and socializing with each other, c) the existence of badoncek (cooperation) 
which maximizes mutual help and help assist in the benefit of the Ummah (A.Hakim, 2012). The strong religious traditions that underlie Minangkabau people's knowledge do not necessarily make them fanaticism or exclusive groups that deny all different groups outside of them(Wanda Fitri, 2015) as stated by(Sanday, 2002), that "Islam in Minangkabau is both a religion and a culture, so that makes them different from other Islamic communities in Indonesia ". Besides that, the results of (Wahidin, 2019) revealed; "Religion as a source of values will give birth to norms that need to be internalized in everyday life.

In other higher levels of social life such as kinship, community and religious (government) there are known terms of deliberation and consensus which are the core teachings of democracy (Tsuyoshi Kato, 2007). The phrase "Sitting together low standing tall", is a concept of socializing ethnic Minangkabau. The concept has an impact on the success of the Minangkabau people in making choices of alliance with people outside their community, awareness of cultural and religious plurality has become part of awareness in the community and state in Minangkabau (Wanda Fitri, 2015).

Integration of Islam and local wisdom of the Minangkabau so that the Minangkabau ethnic students learn both at school and in the Minangkabau community, especially in the families of students so that the culture of tolerance has become a habit in life and the recurring habits that make the character of ethnic Minangkabau students.

\section{B. Description of Religious Tolerance Ethnic Batak students at Xaverius Bukittinggi High School}

Batak ethnic students at Xaverius Bukittiggi High School are a minority population but have the largest number among other minority ethnic group populations, such as Mentawai, Nias, Javanese Malay, and others. Students of Batak ethnicity belong to Catholicism, Protestantism, and Islam. The results of religious tolerance research Batak ethnic students in Xaverius Bukitinggi High School can be seen in the following table:

Table 5. Description of religious tolerance Batak ethnic students at Xaverius Bukittinggi High School

\begin{tabular}{cccc}
\hline Category & Interval & F & \% \\
\hline Tolerance & $\geq 224$ & 16 & 80 \\
\hline Tolerant enough & $148-223$ & 4 & 20 \\
\hline Intolerance & $\leq 147$ & 0 & 0 \\
\hline Amount & & 8 & 100 \\
\hline
\end{tabular}


From the results of the study described in the table above can be interpreted under religious tolerance Batak ethnic students in Xaverius Bukittinggi high school are tolerant as many as 16 people $(80 \%)$, quite tolerant category 4 people $(20 \%)$ and intolerant categories 0 people $(0 \%)$. The results of this study can be understood religious tolerance Batak ethnic students in Xaverius Bukittinggi high school dominated the tolerant category, it means that Batak ethnic attitudes and behaviour are always open, independent, respectful and build positive social interactions among students across religions to achieve a harmonious, peaceful and harmonious life that tends to be tolerant.

The results of the above study are in line with the results of Dewi's research (2005) which explains, "Batak ethnic communities are known for having the concept of openness, spontaneity and aggressiveness both physically and verbally (Rina Suciati, 2017). According to (Irna Minauli, Nilva Desriani, 2006) the Batak ethnicity in their customs is known as the dadap na tolu. Dalihan na tolu, namely expressing emotions in the form of behaviour, speech or facial expression, is also adjusted to the strength or weakness of emotions that are perceived to behave in social life, meaning that Batak ethnic communities have an open tendency to socialize. This openness becomes potential in building interactions for religious tolerance among tolerant people.

Besides ethnic Batak has the view that each individual has a degree of equality, so that in interacting and communicating can be done openly and as is (Bangun; 1986). These cultural views and concepts make the habits and character of Xaverius Bukittingi's high school Batak ethnic students make their attitudes and behaviour tend to be tolerant.

\section{Comparison of Religious Tolerance of Minangkabau ethnic students and Batak ethnic students in Xaverius Bukittinggi High School.}

Minangkabau ethnic students and Batak ethnic students at Xaverius Bukittinggi high school seen generally showed a tendency towards tolerant religious tolerance and generally religious tolerance of Xaverius Bukittinggi high school students can be seen in the following table description: 
Table 5. Description of religious tolerance Students in Xaverius Bukittinggi High School

\begin{tabular}{cccc}
\hline Category & Interval & F & \% \\
\hline Tolerance & $\geq 224$ & 30 & 75 \\
\hline Tolerant enough & $148-223$ & 10 & 25 \\
\hline Intolerance & $\leq 147$ & 0 & 0 \\
\hline Amount & & 8 & 100 \\
\hline
\end{tabular}

From the results of the study described in the table above can be interpreted under religious tolerance Xaverius Bukittinggi students generally categorized as tolerant of 30 people (75\%), the category of tolerant enough as many as 10 people (25\%), while the intolerant category as 0 people $(0 \%)$. These results can be understood religious tolerance Xaverius Bukittinggi high school students in general in class XII dominated by the tolerant category, meaning that attitudes and behaviour of students of Xaverius Bukittinggi high school are always open, independent, respectful and positive social interaction among students Interfaith students achieve a harmonious, peaceful and good harmony in the school environment and society generally tend to be tolerant

The concept and cultural experience of each ethnic group create different conditions and situations. The comparative description of religious tolerance among ethnic Minangkabau and Batak students at Xaverius Bukitinggi High School can be explained through the results of the following research by conducting an Independent T-Test Sample after observing the results of tests of normality and homogeneity. T-test results (Independent sample T-Test) can be seen in the following table:

Table 6. Comparative Test of Religious Tolerance of Minangkabau Ethnic Students and Batak Ethnic Students in Xaverius Bukittinggi High School

\begin{tabular}{l} 
Religious \\
\cline { 2 - 4 }
\end{tabular}


averages (t-test for Mean Equality) in t-test testing must be based on the same assumption of variance. In the line assumed the same variance, a value of 0.165 is obtained. Based on hypothetical assumptions if the value of the T-Test results> 0.05 then Ho is accepted, so there is no significant difference in religious tolerance of ethnic Minangkabau students and Batak ethnic students in Xaverius Bukittinggi High School. Furthermore, it can be seen specifically the differences in religious tolerance of ethnic Minangkabau students and Batak ethnic students from each aspect of religious tolerance. The religious tolerance aspects in question are aspects of attitude and behaviour; a). open (understand, accept and maintain the reality of differences in the concepts of faith and worship of each religion and the flow of belief), b). Freedom in practising the faith and worship of each adherent and religious belief, c). respect the concepts of developing faith and religious worship and the flow of beliefs and d). positive interaction and communication from each religious adherent and the flow of belief (Diane, 2004; Davis, A., 2010; Pamungkas, C., 2014).

To find a comparative picture of religious tolerance among Minangkabau ethnic students and Batak ethnic students in Xaverius Bukittinggi High School, each aspect is explained in the following table:

Table. 9 Comparative Test of Religious Tolerance of Minangkabau Ethnic Students and Batak Ethnic Students in Each Aspect

\begin{tabular}{|c|c|c|c|}
\hline \multirow[t]{2}{*}{$\begin{array}{c}\text { Religious Tolerance Students in Each } \\
\text { Aspect }\end{array}$} & \multicolumn{3}{|c|}{$\begin{array}{l}\text { Levene's Test for Equality of Variances } \\
\text { (Equal variances assumed) }\end{array}$} \\
\hline & $\mathbf{F}$ & Sig. & Sid. (2-tailed) \\
\hline $\begin{array}{l}\text { Open between religious adherents and the } \\
\text { flow of trust in socializing }\end{array}$ & .012 & .914 & .754 \\
\hline Freedom in carrying out religion and or belief. & .165 & .689 & .224 \\
\hline $\begin{array}{l}\text { Respect when worshipping according to } \\
\text { religious faith }\end{array}$ & .001 & .980 & .426 \\
\hline Building positive interfaith interactions. & .187 & .669 & .845 \\
\hline
\end{tabular}

Religious tolerance Students on the open aspect between adherents of religion mean that the attitudes and behaviour of students who can understand, and accept the reality of differences in the concepts of faith and worship and maintain differences in the concepts of faith and worship of each religion. Based on the calculation results of the comparison of two data averages above, it is known that the Levene's Test for Equality of 
Variances column has a significance value of $0.914(\mathrm{p}>0.05)$. This shows that the two variances are the same, so the use of variance to compare population averages ( $\mathrm{t}$-test for Equality of Means) in t-test testing uses the equal variance assumed basis. In the equal variance assumed line, a value of 0.754 is obtained. Based on hypothetical assumptions if the value of TTest results $>0.05$ then Ho is accepted, so there is no significant difference in religious tolerance of Minangkabau and Batak ethnic students in Xaverius Bukittinggi high school on the open aspect between religious adherents and the flow of trust in socializing.

Furthermore, the T-test (comparison) of religious tolerance among Minangkabau and Batak ethnic students at Xaverius Bukittinggi High School on the independent aspect in practising religion and or belief flow means that the awareness of students' attitudes and behaviour; a). provide opportunities for worship at any time to individuals or groups of each religion and creed, b). permit or allow to establish a place/place of worship of followers of religion and beliefs according to the provisions of the legislation in force, and c). allow religious adherents and religious beliefs to worship in their respective places of worship. Based on the calculation results of the comparative test of two data above, it is known that the Levene's Test for Equality of Variances column has a significance value of 0.689 ( $p>0.05$ ). This shows that the two variances are the same, so the use of variance to compare the population average (t-test for Equality of Means) in t-test testing uses the basis of equal variance assumed. In the equal variance assumed line, a value of 0.224 is obtained. Based on hypothetical assumptions if the value of T-Test results> 0.05, then Ho is accepted, so there is no significant difference in the tolerance of ethnic Minangkabau and Batak ethnic students on the freedom aspect in practising religion and or beliefs.

Then the religious tolerance of students on aspects of respect when worshipping according to religious faith means the awareness of attitudes and behaviour of students; a). able to treat religious symbols and religious beliefs, b). tolerate in commemorating religious holidays and religious beliefs, c). giving supporters of the religion and the flow of beliefs to develop faith and devotion to God Almighty, and applying to the adherents of the religion and the flow of faith to do acts of virtue and humanity. Based on the calculation results of the comparison of the two data averages above it is known in column Levene's Test for Equality of Variances has a 
significance value of $0.980(\mathrm{p}>0.05)$. This shows that the two variances are the same, so the use of variance to compare the population average (t-test for Equality of Means) in t-test testing uses the basis of equal variance assumed. In the equal variance assumed line, a value of 0.426 is obtained. Based on hypothetical assumptions if the value of the T-Test results>0.05, then Ho is accepted, so there is no significant difference in the religious tolerance of ethnic Minangkabau students and Batak ethnic students on the aspects of respect when worshipping practising religion and or the flow of interfaith beliefs of students.

Furthermore, the T-test (comparison) of students' religious tolerance on aspects of building positive social interactions across faiths and beliefs. This means that; awareness of students' attitudes and behaviour; A). cooperate and or please help in maintaining order and peace in social life, b). collaborate and or assist in educating the life of education in the fields of economics, health, law, politics, social, culture, community tourism, c). collaborate and help with humanitarian assistance for victims of natural disasters, d). cooperate and or please help in caring for and preserving nature. Based on the calculation results of the comparison of the two data averages above, it can be seen that the column Levene's Test for Equality of Variances has a significance value of 0.669 ( $>>0.05)$. This shows that the two variances are the same, so the use of variance to compare population averages ( $\mathrm{t}$-test for Mean Equality) in t-test testing can be done based on the same variant assumptions. In the line assumed the same variance, a value of 0.845 is obtained. Based on the hypothesis assumption if the value of the T-Test results> 0.05, then Ho is accepted, so there is no significant difference in religious tolerance of ethnic Minangkabau students and Batak ethnic students in Xaverius Bukittinggi high school on positive aspects of interfaith interaction.

From the comparative test results of religious tolerance in each of the above aspects, it can be explained that there is no significant difference in the religious tolerance of Minangkabau ethnic students and Batak ethnic students in Xaverius Bukittinggi High School on each aspect. Although there is no significant difference from the comparison test, the score experiences a difference of several points which can be seen in the following chart: 


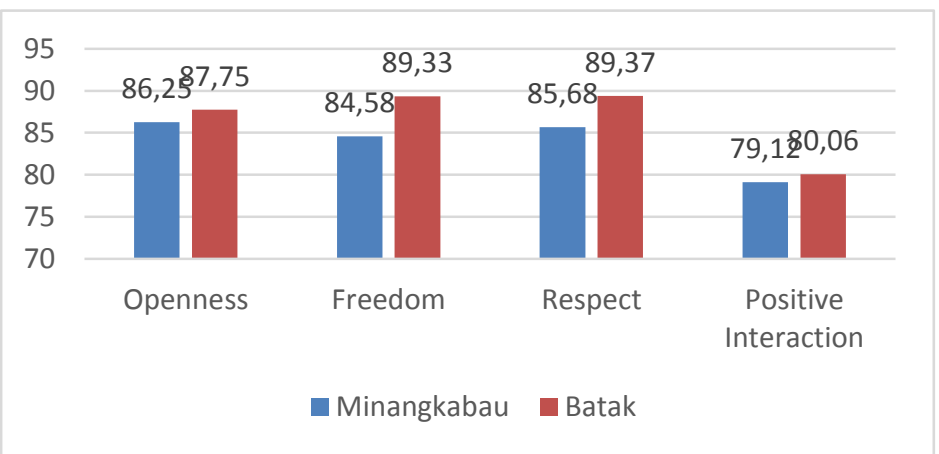

Graphic 1. Description of the comparison of religious tolerance Minangkabau ethnic students with Batak ethnic students at Xaverius Bukittinggi High School

From the graph above the results of the study illustrate the comparison of religious tolerance scores of Minangkabau ethnic students with Batak ethnic students in Xaverius Bukittinggi high school seen from; a). aspects of openness in understanding, accepting and maintaining the reality of differences in the concepts of faith and worship of each religion and the flow of trust the average percentage score of ethnic Minangkabau students is $86.25 \%$ while the average score of percentage of Batak ethnic students is $87.75 \%$ so there is a difference in score of $1.5 \%$, then, b). in the aspect of freedom of worship according to religion and belief, the average percentage score of Minangkabau ethnic students was $84.58 \%$ while the average percentage score of Batak ethnic students was 89.33 , so there was a difference in the score of $4.75 \%$. Then c). on the aspect of respect for worship according to religious beliefs and beliefs, the average percentage score of the Minangkabau ethnicity was $85.68 \%$ while the average percentage of Batak ethnic students was 89.37, so there was a difference in the score of $3.69 \%$. Furthermore, d). on the aspect of building positive interfaith interactions, the average percentage score of Minangkabau ethnic students was $79.12 \%$ while the average percentage of Batak ethnic students was 80.06 , so there was a difference in score of $0.94 \%$.

From the scores of each aspect of the student's religious tolerance, the scores of Batak ethnic students are greater than those of the Minangkabau ethnic students. This is in line with the results of (Hanum, 2009) which revealed that students (individuals or minority groups) who are in the majority group tend to be more tolerant than the majority group, this is due to the demands of the situation and conditions making minority groups feel the need to strive for self-adjustment that is more proactive towards majority groups (Hanum, 2009). The proactive attitude of Batak ethnic 
students' self-adjustment is reflected in the concept of Batak ethnic culture in their customs known as the term of dalihan na tolu, which is trying to behave and act openly in socializing (Monika, 2012). Besides ethnic Batak has the view that each individual has a degree of equality, so that in interacting and communicating can be done openly and as is (Bangun; 1986). These cultural views and concepts make the habits and character of Xaverius Bukittingi's high school Batak ethnic students make their attitudes and behaviour tend to be tolerant.

Although the Minangkabau ethnic students form the majority group in the school, the attitude of acceptance and openness of the Minangkabau ethnic students towards other ethnic groups in socializing is reflected in Minangkabau customs upholding equality and balance with the terms, dima bumi dipijak disinan langik di junjung(where the earth is grounded in socializing there sky upheld), namely the principle of adapting to society wherever located, regardless of ethnicity and religion, then the attitude of katuju dek awak, katuju dek urang (good for us, people are also happy), as for the meaning of culture that reflects the attitude of togetherness in society and associate with each other concerning each other, and the existence of badoncek (cooperation) whose maxims help one another help and assist in the benefit of the Ummah (A.Hakim, 2012).

Cultural wisdom possessed by Batak ethnic students and Minangkabau ethnic students who are open to each other and can adapt themselves so that students' religious tolerance develops rapidly. The development of ethnic Batak and Minangkabau harmonization is also reflected in the broader level of community life (Adri Febrianto, 2011, Meldawati, 2017, Nofriadi, 2017).

The results of this study are in line with the recognition of the Principal of Xaverius, Silvia Rosnani (2019) when meeting during the preliminary study, she stated: teachers, between students and other students, to strengthen and optimize socialization, we at the school have arranged a program of activities guided by the Religious Teachers, Citizenship and Counseling Teachers are now being implemented, ". The statement strengthens the results of the research (Widhayat, 2018) explains:" One of the supporters in the formation of tolerance is teachers, student associations in the school environment, student associations with teachers who have positive values in the formation student tolerance ". The statements and 
results of this study reinforce the opinion of (Casram, 2016) who revealed;" The idea of religious tolerance must be built through the active participation of all members of diverse religious communities to achieve the same goals based on togetherness. s, inclusive attitudes, respect, and mutual understanding of the implementation of certain rituals and doctrines of each religion.

Besides that, a statement from Xaverius Bukittinggi High School Religion Teacher, Aulia Rahman (2019), was revealed; "The religious tolerance of Xaverius Bukittinggi high school students is being formed and a program of faith-building activities is held every Friday morning and carried out following the religion and beliefs of each student in the school". Furthermore, Counseling Teacher Rika Saputtri (2019) added; religious tolerance Xaverius Bukittinggi High School students have been implemented following the program compiled by the School. Cultivation of religious tolerance is also carried out through school guidance and counselling services, such as group counselling and guidance activities, individual counselling, outbound activities, etc., but the strategies and facilities available are still limited and need to support more optimal activities so that religious tolerance of students becomes more tolerant ". The services provided by the counselling teacher strengthened Solehuddin's research findings (2019) showing that the topic of counselling services by participating BK teachers included the value of ongoing global partnerships, independence, nationalism, integrity, and religiosity carried out through individual and teamwork, potential developing student tolerance at school (M.Solehuddin, 2019).

The statement of Xaverius Bukittinggi High School teachers reinforces the opinion of (Rustam Ibrahim, 2013) about the basic requirements that are met by schools to foster religious tolerance namely; a). The practice of education always emphasizes the principle of justice so that all students receive a fair and equal education, b). The learning process is kept away from the nature of bias and stereotypes, c). The learning process leads to the development of students' awareness of themselves, respect for other cultures outside of themselves, and being able to work together amidst existing cultural differences(Rustam Ibrahim, 2013).

In addition to this, the development of religious tolerance also requires behaviour change throughout the environment. According to 
Skinner that the most important element in learning is reinforcement or reinforcement (Dalyono, 2015). Strengthening can be divided into two, namely positive reinforcement and negative reinforcement. Positive reinforcement is reinforcement used to stimulate good behaviour. Examples are praise, values, gifts. Whereas negative reinforcement is a reinforcement to reduce unwanted behaviour or actions, for example, giving penalties, adding tasks, etc. The effectiveness of reinforcement in behaviour depends on various factors, including the frequency or schedule of reinforcement (Dalyono, 2015). Thus the religious tolerance of Xaverius Bukittinggi high school students is increasingly needed supporting factors and developers including program activities, strategies, material content and creating a positive atmosphere of harmony.

\section{CONCLUSION AND RECOMMENDATION}

From the results of this study it can be concluded that the description of religious tolerance of Xaverius Bukittinggi high school students is generally $75 \%$ tolerant, $25 \%$ tolerant enough category, seen from each group; religious tolerance Minangkabau ethnic students 70\% tolerant category and 30\% moderately tolerant category, $80 \%$ ethnic Batak student religious tolerance category tolerant, and $20 \%$ moderately tolerant category. Judging from these results, the religious tolerance of Xaverius High School students is generally dominated by the tolerant category, which means that the attitudes and behaviour of Xaverius Bukittingi High School students achieve a harmonious, peaceful and harmonious life both in the school environment and in society generally tend to be tolerant. Furthermore, this research hypothesis states that it is accepted that there is no significant difference in the tolerance of ethnic Minangkabau students and Batak ethnic students in Xaverius Bukittinggi secondary school. From the results of this study can be taken into consideration for developing religious diversity counselling and manage multicultural guidance and counselling service programs in high schools.

\section{REFERENCES}

Bahari, H. MA., (ed.). (2010). Toleransi Beragama Mahasiswa, Jakarta: Kementerian Agama RI, Badan Litbang dan Diklat, Puslitbang Kehidupan Keagamaan.

Bangun, T. (1986). Manusia Batak Karo, Jakarta, Inti Idayu Press 
Bashori A. Hakim, (2012). Kerukunan Umat Beragama di Sumatera Barat. Jurnal Multikultural \& Multireligius (Harmoni), Vol. 11 April - Juni 2012, 109-111, Retrieved from https://jurnalharmoni.kemenag.go.id

Casram. (2016). Membangun Sikap Toleransi Beragama Dalam Masyarakat Plural. Wawasan: Jurnal Ilmiah Agama dan Sosial Budaya 1, 2 (Juli 2016): 187-198.

Dalyono, Muhammad. (2015). Psikologi Pendidikan. Jakarta: Rineka Cipta Ilmiah Agama Dan Sosial Budaya.

Davis, A. (2010). Defending religious pluralism for religious education. Ethics and Education, 5(3), 189-202.

Dewi, L. Zahrasari. (2005). Pengalaman, Ekspresi, dan Kontrol Marah Pada orang Batak dan Jawa. Jurnal Psikologi Fakultas Psikologi UNIKA Atma Jaya Vol. 16, No. 2: Jakarta

Farida Hanum, Pendidikan Multikultural Sebagai Saran membentuk Karakter Bangsa (Dalam Perspektif sosiologi Pendidikan), Makalah Seminar Regional Universitas Regional, 14 desember 2009.

Febrianto Andi, Etmi Hardi \& Bustaman, (2011). Orang Minangkabau dan Batak Mandailing di Nagari Buayan. Jurnal Humanus, Vol X No 1, 1-2

Hadi, Dwi Winanto, dkk, (2007). Analisis Sikap Toleransi di Indonesia dan Faktor-Faktor, Pusat Data dan Statistik Pendidikan dan Kebudayaan Sekretariat Jenderal Kementerian Pendidikan dan Kebudayaan

Hermawati, Rina Caroline Paskarina, N. R. (2016). Toleransi Antar Umat Beragama di Kota Bandung. UMBARA: Indonesian Journal of Anthropology, Volume 1, 105-115.

Widhayat, Wahyu, Oksiana J, (2018). Sikap Toleransi Antar Ummat Beragama Pada Siswa SMA Muhammadiyah 4 Porong, Jurnal Kajian Moral dan Kewarganegaraan. Volume 06 Nomor 02 Jilid III Tahun $2018,596-610$

Ibrahim, Rustam. (2013). "Pendidikan Multikultural: Pengertian, Prinsip, dan Relevansinya dengan Tujuan Pendidikan Islam”. Jurnal ADDIN, 7 (1): 129154.)

Irianto, Agus. (2009). Statistik Konsep Dasar dan Aplikasinya. Jakarta: Kencana

Kato, Tsuyoshi. (1982). Matriliny and Migration: Evolving Minangkabau Traditions in Indonesia. Ithaca, New York: Cornell University Press, $12-13$ 
Ahsanul, Khalikin. (2010). Toleransi Beragama di Daerah Rawan Konflik. Jakarta, PUSLITBANG KEMENAG RI

Meldawati,(2017). Harmonisasi Antara Etnik Jawa Minang Batak Studi Kasus Di Daerah Di Jambak Kabupaten Pasaman Barat. Jurnal Bakaba, Volume 6, Nomor 2, Juni-Desember 2017, 5-6

Minauli, Irna, Nilvia D, Yosetta, (2006). Perbedaan Penanganan Kemarahan Pada Situasi Konflik Dalam Keluarga Suku Jawa, Batak dan Minangkabu. Journal Psikologia, Vol 2 No 1 Juni 2006, 1-6

Muzayanah, Umi, (2017). Indeks Pendidikan Multikultural dan Toleransi Siswa SMA/K di Gunung Kidul dan Kolonprogo. EDUKASI: Jurnal Penelitian Pendidikan Agama dan Keagamaan, 15(2), 2017, 223-240

Nisfiannoor, Muhammad. (2009). Pendekatan Statistika Modern .Jakarta: Salemba Huamanika.

Nofriadi, Safwan Rozi. (2019). Penerapan Nilai Toleransi Antar Budaya dalam Pelaksanaan Hukum Kewarisan Islam pada Masyarakat Perbatasan di Rao Pasaman Sumatera Barat. Ijtihad (Jurnal Wacana Hukum Islam dan Kemanusiaan) Vol. 17, No. 1 (2017), pp. 85-112

Pamungkas, C. (2014) . Toleransi Beragama Dalam Praktik Sosial Studi Kasus Hubungan Mayoritas dan Minoritas Agama di Kabupaten Buleleng. Epistemé (Vol. 9), LIPI.

Rahman, Aulia (2019). Wawancara Penjelasan Program Kegiatan Toleransi Beragama Siswa di SMA Xaverius Bukittinggi, jumat, 2 Agustus 2019, $09.30 \mathrm{WIB}$

Rosnani, Silvia (2019). Wawancara Penjelasan Profil SMA Xaverius Bukittinggi, jumat, 2 Agustus 2019, 09.00 WIB

Sabil Mokodenseho, (2008). Toleransi Beragama Dan Pembelajaran Agama Islam: Harmoni Masyarakat Minoritas Muslim Manado, Prosiding Seminar Nasional \&Temu Ilmiah Jaringan Peneliti IAI Darussalam Blokagung Banyuwangi.

Samad, Duski. (2019). Intoleransi di Sumatera Barat, Bulletin suara kampus, Kolom Opini edisi, Senin, 25/02/2019, http://www.suarakampus.com/?mod=opini\&se=detil\&id=245

Sanday, Peggy Reeves. (2002). Matriarchy and Islam Post 9/11: A Report from Indonesia, Sanday University of Pennsylvania, Published in Anthropology News, Vol. 43, No. 9, Dec. 2002, page 7. Retrieved from 
https://web.sas.upenn.edu/psanday/reports/matriarchy-and-islam-post911-a-report-from-indonesia/ [access on 5th December 2019]

Saputtri, Rika (2019). Wawancara Penjelasan Program BK Multikultural di SMA Xaverius Bukittinggi, jumat, 2 Agustus 2019, 09.55 WIB

Solehudin, M, (2019). Sustainable Counseling Values By Indonesian Preschool Tteachers To Prepare More Tolerant Young Global Citizens. Journal of Multicultural Studies in Guidance and Counseling, Volume 3, No. 2, 119-136, http://ejournal.upi.edu/index.php/jomsign

Suciati Rina, Ivan Muhammad Agung, (2016). Perbedaan Ekspresi Emosi pada orang Batak, Jawa, Melayu dan Minangkabau, Jurnal Psikologi, Volume 12 Nomor 2, 105-106, Retrieved from http://ejournal.uinsuska.ac.id/index.php/psikologi/article/viewFile/3236/2036

Tillman, Diane. (2004). Pendidikan Nilai Untuk Kaum Muda Dewasa (Terjemahan Risa Pratono). Jakarta: Grasindo

Toto Suryana, (2011). Konsep dan Aktualisasi Kerukunan Antar Umat Beragama, Jurnal PAI- Taklim, Vol 9. No2

Wahidin, Mamat Supriatna, (2019). Religious Experience As a Personal Guidance Base. Journal of Multicultural Studies in Guidance and Counseling, Volume 3, No.1, Maret 2019: Page 35-50 ISSN 2549-7065 $\begin{array}{llll}\text { (print) } \| & \text { ISSN } & \text { 2549-7073 }\end{array}$ http://ejournal.upi.edu/index.php/jomsign

Wanda Fitri, (2015). Plurasilem di Tengah Masyarakat Santri Minang, Sebuah Pengenalan Pluralitas Lokal di Sumatera Barat. Journal of Islamic \& Social Studies (Islam Realitas),: Vol. 1, No.1, Januari-Juni 2015, 56-57

Yasmarni, Tati. (2018). Pengurustumaan Gender di Kota Bukitinggi 2018 (ppt), http://www.bukittinggikota.go.id/download/PUG\%20utk\%20website.pd $\underline{f}$

Zainal Arifin, Muhammat, Oksina JN, (2018). Perbandingan Sikap Toleransi Beragama Antara Peserta Disik di Boarding School dam Non Bording Schol di SMP Luqman Al-Hakim Ssurabaya dan SMPN 21 Surabaya, Jorunal Kajian Moral dan Kewarganegaraan. Volume 06 Nomor 03 Tahun 2018, 1091-1105 